\title{
Progressive multifocal leukoencephalopathy and sarcoidosis under interleukin 7
}

The price of healing

Aurélien Guffroy, MD, PhD, Morgane Solis, PharmD, PhD, Vincent Gies, PharmD, PhD, Yannick Dieudonne, MD, Cornelia Kuhnert, MD, Cédric Lenormand, MD, PhD, Laurent Kremer, MD, PhD, Anne Molitor, PhD, Raphaël Carapito, PhD, Yves Hansmann, MD, PhD, Vincent Poindron, MD, PhD, Thierry Martin, MD, PhD, Sandrine Hirschi, MD, and Anne-Sophie Korganow, MD, PhD

Neurol Neuroimmunol Neuroinflamm 2020;7:e862. doi:10.1212/NXI.0000000000000862

\section{Abstract}

\section{Objective}

To report the association of JC virus infection of the brain (progressive multifocal encephalopathy $[\mathrm{PML}]$ ) during the course of sarcoidosis and the challenging balance between immune reconstitution under targeted cytokine interleukin 7 (IL7) therapy for PML and immunosuppression for sarcoidosis.

\section{Methods}

Original case report including deep sequencing (whole-exome sequencing) to exclude a primary immunodeficiency (PID) and review of the literature of cases of PML and sarcoidosis.

\section{Results}

We report and discuss here a challenging case of immune reconstitution with IL7 therapy for PML in sarcoidosis in a patient without evidence for underling PID or previous immunosuppressive therapy.

\section{Conclusions}

New targeted therapies in immunology and infectiology open the doors of more specific and more specialized therapies for patients with immunodeficiencies, autoimmune diseases, or cancers. However, before instauration of these treatments, the risk of immune reconstitution inflammatory syndrome and potential exacerbation of an underlying disease must be considered. It is particularly true in case of autoimmune disease such as sarcoidosis or lupus.

\author{
Correspondence \\ Dr. Guffroy \\ aurelien.guffroy@chru-strasbourg.fr
}




\section{Glossary}

BREF = "Batterie rapide d'efficience frontale" test (also called Dubois' test); IRIS = immune reconstitution inflammatory syndrome; JCV = JC virus; MMSE = Mini Mental State Examination; PID = primary immunodeficiency; PML = progressive multifocal encephalopathy; STAT1 GOF = gain-of-function in STAT1 (signal transducer and activator of transcription 1) gene.

Progressive multifocal encephalopathy (PML) is a devasting demyelinating disease of the brain white matter described for the first time by Äström and colleagues in 1958 in a context of hematologic malignancy. PML is the consequence of the glial cell opportunistic infection by the human JC virus (JCV). Although asymptomatic JCV infection usually occurs in childhood and remains clinically silent in adult throughout life, active JCV replication in the brain could occurs in primary or secondary immunodeficiencies (mainly AIDS and hematologic malignancies) leading to PML. Immunosuppressive or immunomodulatory drugs such as natalizumab in MS or rituximab have already been linked to PML, and some cases have been reported in sarcoidosis with severe $\mathrm{CD}^{+}$lymphopenia. ${ }^{1}$ Currently, achievement of immune reconstitution is the only curative option. In this view, interleukin 7 (IL7) or anti-PD1 therapies have been suggested to help the control of JCV in standing the immune response to the virus. ${ }^{2-4}$

\section{Case report}

A 45-year-old man with PML was referred for acute respiratory failure and hypercalcemia after IL7 treatment in the context of underlying thoracic sarcoidosis. His medical history started 3 months with progressive dyspnea and cough revealing a mild micronodular infiltrate and mediastinal lymphadenopathy on the chest CT (figure). A bronchial biopsy showed a noncaseating granuloma. He developed severe lymphopenia up to $350 / \mathrm{mm}^{3}$ (normal $>1,500 / \mathrm{mm}^{3}$ ). Concomitantly, cognitive impairment (BREF 10/18; MMSE 25/ 30), frontal syndrome with perseverance, aphasia, and speech disturbance were noticed. First referred in psychiatry for unusual behavior, he was then hospitalized in the neurology department where the diagnosis of PML was made based on suggestive MRI demyelinating lesions of the white matter and positive JCV load in serum and CSF (figure and table 1). At this time, he did not receive any therapy for sarcoidosis. His cognitive impairment became worse (BREF 7/18; MMSE $17 / 30$ ) during the first days of hospitalization, and a compassionate regiment of IL7 was started. Thanks to a 4-week regiment of IL7 at $10 \mathrm{mg} / \mathrm{kg} / \mathrm{wk}$, the neurologic symptoms improved, and the viral load felt to undetectable value (figure and table 1). Recent sharply demarcated erythema with fine scaling of seborrheic areas (presternal region and hairy zones of the face, scalp, and groin) along with erythemato-squamous plaques of the elbows was noticed, strongly suggestive of either sebopsoriasis or profuse seborrheic dermatitis. Skin biopsy with histopathologic examination demonstrated only nonspecific dermatitis without any granuloma, thus ruling out psoriasiform sarcoidosis. At the same time, the patient had
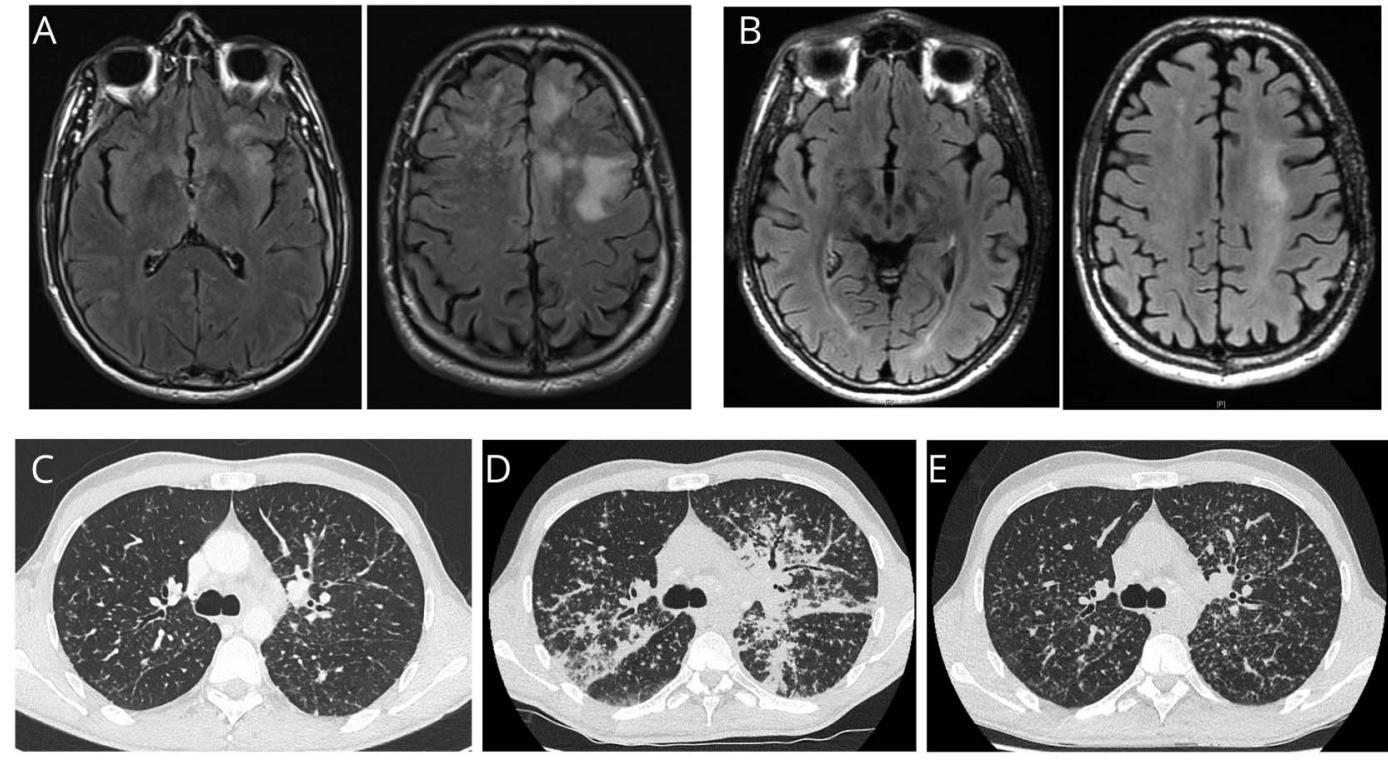

MRI (axial, fluid-attenuated inversion recovery [FLAIR] sequences) of the brain at diagnosis of PML (A) and after IL7 therapy (B) showing a regression of inflammatory lesions of the white matter of the frontoparietal lobes predominant in the left hemisphere of the brain. TDM of the chest before IL7 showing light micronodular interstitial infiltrate related to sarcoidosis (C), dramatic worsening after 4 doses of IL7 therapy related to immune reconstituting syndrome (D), and improvement 3 months later after IL7 discontinuation, steroids, and hydroxychloroquine (E). 
Table 1 Clinical and biological features

\begin{tabular}{|c|c|c|c|c|c|}
\hline & Diagnosis & After 4 wk of IL7 & $M+1$ & $M+3$ & $M+6$ \\
\hline \multicolumn{6}{|l|}{ Clinical symptoms } \\
\hline Weight & 62 & 63 & 65 & 65 & 65 \\
\hline Fever $\left(>38.2^{\circ} \mathrm{C}\right)$ & No & Yes & Yes & No & No \\
\hline Dyspnea (NYHA) & I/IV & II/IV & I/IV & No & No \\
\hline Confusion & Yes & No & No & No & No \\
\hline Aphasia & Yes & No & No & No & No \\
\hline BREF & $7 / 18$ & ND & ND & ND & $18 / 18$ \\
\hline MMSE & $17 / 30$ & ND & ND & ND & $30 / 30$ \\
\hline Splenomegaly & No & No & Yes $^{a}$ & No & No \\
\hline Autoimmune manifestations & No & No & Yes (psoriasis flare-up) & Yes (psoriasis flare-up) & No \\
\hline Therapies & None & IL7 & Steroïds + HCQ & Steroïds + HCQ & $\mathrm{HCQ}$ alone \\
\hline \multicolumn{6}{|l|}{ Biological parameters } \\
\hline Lymphocyte count (/mm3) & 340 & 400 & 400 & 540 & 560 \\
\hline $\mathrm{CD}^{+} \mathrm{T}$ cells & 120 & NA & 141 & 150 & 150 \\
\hline Hypercalcemia (mmol/L) & No & NA & Yes (3.1) & No & No \\
\hline 1-25-OH-VitD3 & NA & NA & $143 \mathrm{ng} / \mathrm{L}(\mathrm{N}<90)$ & NA & Normal \\
\hline Conversion enzyme activity & 65.8 & NA & Normal & Normal & Normal \\
\hline Gamma-globulinemia (g/L) & NA & NA & $4.1 \mathrm{~g} / \mathrm{L}$ & NA & $7.4 \mathrm{~g} / \mathrm{L}$ \\
\hline \multicolumn{6}{|l|}{ JCV load (copies/mL) } \\
\hline Serum & 15,000 & 1,400 & 712 & 112 & Undetectable \\
\hline CNS & 150,000 & NA & NA & NA & NA \\
\hline \multicolumn{6}{|l|}{ Radiology } \\
\hline MRI & Yes & No & Yes (improve) & No & Yes (improve) \\
\hline 18F-FDG-TEP-TDM & Yes & No & $Y_{e s}^{a}$ & No & No \\
\hline Chest CT & Yes & No & Yes (worsening) & No & Yes (improve) \\
\hline
\end{tabular}

Abbreviations: $\mathrm{HCQ}=$ hydroxychloroquine; IFN = interferon; JCV = JC virus; NA = not available; ND = no data; $\mathrm{NYHA}=$ New York Heart Association.

a 18F-FDG-TEP-TDM show an uptake of the spleen, the lung, and hypermetabolism of the chest and coealio-mesenteric adenopathies.

hypercalcemia and required oxygen with a serious worsening of his micronodular lung infiltrate (figure). Bronchoalveolar lavage showed a predominant lymphocytosis (86\%) with 5,8 CD4:CD8 ratio and negative microbiology. One 25-OH-vitamin D3 activity was elevated $(143 \mathrm{ng} / \mathrm{L}$, normal $<90)$. Flareup of sarcoidosis was suspected. He was then transferred to the intensive care unit for acute respiratory failure with a huge worsening of his interstitial lung disease treated with nasal oxygen, and hyperhydration was given with bisphosphonates (pamidronate $90 \mathrm{mg}$ IV) to control calcemia (figure).

Several recent observations and cases series support the hypothesis of underlined inherited immunodeficiency in PML. Moreover, granuloma is a frequent symptom revealing a primary immunodeficiency (PID) (in almost $20 \%$ of cases in common variable immunodeficiency for example). In this way, we decide to perform thorough immunophenotyping and genetic explorations. Analysis of his immune status as well as whole-exome sequencing analysis of the patient with his 2 parents did not reveal any evidence for PID.

IL7 was stopped. An immunosuppressive treatment of sarcoidosis was introduced and associated with a tight control of blood JCV load (table 1). Solumedrol ( $40 \mathrm{mg}$, twice a day) was started, carefully relayed after 5 days by moderate dose of oral steroids (prednisone $30 \mathrm{mg} / \mathrm{d}$ ) with a decreasing protocol for 6 months and prophylactic treatments (cotrimoxazole and valaciclovir). In addition, hydroxychloroquine (400 $\mathrm{mg} / \mathrm{d}$ ) was started as a steroid-sparing agent. Under these therapies, sarcoidosis and psoriasis improved. PML did not 
relapse during the 6 months of follow-up. However, the lymphopenia persisted around $600 / \mathrm{mm}^{3}$.

\section{Methods}

\section{Whole-exome sequencing}

Genomic DNA was isolated from patient and parents' peripheral blood or saliva using standard protocols. Exome sequencing libraries were prepared with the Twist Library Preparation Kit and captured with Human Core Exome probes extended by Twist Human RefSeq Panel (Twist Bioscience, San Francisco, CA) following the manufacturer's recommendations. Paired-end $(2 \times 75 \mathrm{bp})$ sequencing was performed on a NextSeq500 sequencer (Illumina, San Diego, CA). Before any processing, quality control was performed using FastQC. The raw reads data were next mapped using the Burrows-Wheeler Alignment tool. For each sample, average target read coverage was at least 60 -fold. After read mapping, further quality indicators were calculated from the resulting BAM file using SAMtools, Qualimap. Variant calling was performed using the GATK HalotypeCaller of the GATK software suite. The annotation was performed by VEP, the Ensembl Variant Effect Predictor. We focused only on protein-altering variants (missense, nonsense, splice site variants, and coding indels) with alternative allele frequencies $<0.005$ in the 1000 Genomes Project, the Genome Aggregation Database, the Exome Aggregation Consortium, and an internal exome database including $\sim 700$ exomes. To identify potential causal variants, we further filtered the variants based on a de novo and recessive mode of inheritance.

\section{Statistics}

Data are presented as median (range) or frequency (\%) with 95\% CIs. Statistical analyses were performed using JMP 7.0.

\section{Data availability}

Anonymized data will be shared by request from any qualified investigator.

\section{Discussion}

To date, only few cases of sarcoidosis and PML have been reported (table 2). The main cause of the immunodeficiency leading to such opportunistic infections in this situation remains unclear. Indeed, lymphopenia, and mainly the $\mathrm{CD}^{+-}$ lymphocytes decreased, is usually considered as a redistribution of cells (demargination) in the organs involved by the disease and is not considered at risk for infections. Nonetheless, some case reports or series report severe or opportunistic infections occurring in less than $5 \%$ of cases of sarcoidosis. ${ }^{5,6}$ The most frequent infections are Cryptococcus, mycobacterial infection, nocardiosis, histoplasmosis, pneumocystis, and Aspergillus infections. Their occurrence is closely linked not only to the severity (neurologic form of sarcoidosis) and activity of the disease but also to the immunosuppressive therapy (steroids in first and cyclophosphamide). ${ }^{5}$
PML is rarer than other opportunistic infections in sarcoidosis with a very poor prognosis. Our review of literature ( $\mathrm{n}=41$ cases) identifies a median age of 47 years (range 24-74 years) with a sex ratio (M/F) of 1.9 (table 2) and highlights a mortality rate of $61.5 \%$ at last follow-up. Unlike other opportunistic infections, PML may occur in untreated patients (table 2). ${ }^{1}$ In this context, it is of importance to make the differential diagnosis with neurosarcoidosis, which required the use of intensive immunosuppressive therapy. Patients with sarcoidosis and opportunistic infections, especially with no history of immunosuppressive treatment, may belong to a more sensitive subgroup of patients with inherited susceptibility factors. In this view, such factors described in inherited pediatric and familial cases of sarcoidosis involving autophagy pathway or T-cell activation pathway could be crucial for response against pathogens. ${ }^{7}$ Moreover, it is also important to consider the hypothesis of PID with granulomatous manifestations and opportunistic infections (PML) in some combined immunodeficiencies (i.e., Immunodeficiency, Centromeric region instability, Facial anomalies syndrome, DOCK8 deficiency, STAT1 GOF or other combined immunodeficiencies). ${ }^{8}$ In our case, we excluded the eventuality of an inherited error of immunity by several arguments: (1) the age at onset of the opportunistic infection and the past medical history of the patient and his family; (2) the late onset of lymphopenia with prior normal blood examinations; and (3) the wholeexome analysis that excluded a known mutation in PIDrelated genes.

PML, caused by invasive JCV infection of the brain, is a poor prognosis affection with a fatal outcome in weeks or months in the absence of immune reconstitution. Recently, IL7 cytokine therapy and anti-PD1 monoclonal therapy have been proposed to restore an immunity against JCV in a context of secondary immunodeficiency, with or without vaccination strategies. ${ }^{2,4}$ Before using such therapies, it is very important to consider, however, (1) the risk of immune reconstitution inflammatory syndrome (IRIS) and (2) the potential exacerbation of an underlying disease or the emergence of secondary immune/inflammatory manifestations. It is particularly true in case of autoimmune disease such as sarcoidosis or lupus in which imbalance in immune-activating cytokine such as IL7 (one of the most important cytokines to T-cell expansion and activation) could favor a flare. Mechanisms leading to the worsening of a previous inflammatory/autoimmune situation have already been described not only in PML associated with AIDS but also in apparently non-immunocompromised patients. $^{9}$

In our case, the challenging point was to restore the immunity against JCV and to control the sarcoidosis activity. IRIS has been well described in HIV-infected patients as a paradoxical reaction after introduction of the treatment. Even if rare, IRIS can potentially occur in all granulomatous diseases and not just infectious ones. 
Table 2 Literature review of PML cases and sarcoidosis

\begin{tabular}{|c|c|c|c|c|c|c|c|c|}
\hline References & $\begin{array}{l}\text { Cases (sex/ } \\
\text { age at PML } \\
\text { diagnosis, y) }\end{array}$ & $\begin{array}{l}\text { Therapies } \\
\text { before } \\
\text { PML }\end{array}$ & $\begin{array}{l}\text { Time from } \\
\text { diagnosis of } \\
\text { sarcoidosis to } \\
\text { PML (mo) }\end{array}$ & $\begin{array}{l}\text { Lymphocyte } \\
\text { count } \\
\left(/ \mathrm{mm}^{3}\right)\end{array}$ & $\begin{array}{l}\text { CD4 }^{+} \\
\text {count } \\
\left(/ \mathrm{mm}^{3}\right)\end{array}$ & Treatment & Tolerance & $\begin{array}{l}\text { Outcome } \\
\text { of PML }\end{array}$ \\
\hline $\begin{array}{l}\text { Christensen E et al. } \\
\text { Acta Psychiatr } \\
\text { Neurol Scand. } 1955\end{array}$ & $M / 59$ & No & 0 & NA & NA & No & NA & Death \\
\hline $\begin{array}{l}\text { Headington JT. } \\
\text { Neurology. } 1962\end{array}$ & $\mathrm{M} / 41$ & NA & NA & NA & NA & NA & NA & \\
\hline $\begin{array}{l}\text { Mariott PJ et al. J } \\
\text { Neurol Neurosurg. } \\
1975\end{array}$ & $\mathrm{~F} / 52$ & CS & 72 & NA & NA & $\begin{array}{l}\text { Cytarabine (2 mg/ } \\
\mathrm{kg} / \mathrm{d})\end{array}$ & Good & Improve \\
\hline Smith CR et al. 1982 & $\mathrm{M} / 32$ & CS & 108 & NA & NA & Cytarabine & NA & Death \\
\hline $\begin{array}{l}\text { Rosenbloom MA } \\
\text { et al. Chest. } 1983\end{array}$ & F/59 & CS & 0 & 820 & NA & CS (increased) & NA & Death \\
\hline $\begin{array}{l}\text { Iannarella G et al. } \\
\text { Ann Med Int. } 1992\end{array}$ & F/68 & No & 26 & NA & 500 & CS and acyclovir & NA & Death \\
\hline $\begin{array}{l}\text { Steiger MJ et al. } \\
\text { Ann Neurol. } 1993\end{array}$ & $M / 37$ & NA & 0 & NA & NA & $\begin{array}{l}\text { Cytarabine, } \\
\text { acyclovir, and } \\
\text { IFN-a }\end{array}$ & NA & Improve \\
\hline $\begin{array}{l}\text { Heide W. Ann } \\
\text { Neurol. } 1995\end{array}$ & $M / 47$ & CS & 132 & NA & NA & $\begin{array}{l}\text { Cytarabine and } \\
\text { IFN-a }\end{array}$ & NA & Death \\
\hline $\begin{array}{l}\text { Hammarin AL et al. } \\
\text { J Clin Microbiol. } \\
1996\end{array}$ & $M / 51$ & NA & NA & NA & NA & NA & NA & NA \\
\hline $\begin{array}{l}\text { Jochum W et al. } \\
\text { Acta Neuropathol. } \\
1997\end{array}$ & $M / 54$ & NA & NA & NA & NA & NA & NA & NA \\
\hline $\begin{array}{l}\text { Olindo S. Rev Neuro } \\
\text { (Paris). } 2000\end{array}$ & $F / 47$ & CS & 168 & NA & NA & NA & NA & Death \\
\hline $\begin{array}{l}\text { Mackowiak- } \\
\text { Cordoliani MA } \\
\text { et al. Rev Neurol } \\
\text { (Paris). } 2001\end{array}$ & $\mathrm{~F} / 70$ & CS/MTX & NA & 1,000 & $<300$ & Cidofovir and IL2 & NA & Death \\
\hline $\begin{array}{l}\text { Völker HU et al. Clin } \\
\text { Neurol Neurosurg. } \\
2007\end{array}$ & $M / 49$ & CS & 0 & 580 & 258 & IVIg and cidofovir & NA & Death \\
\hline $\begin{array}{l}\text { Owczarczyk et al. } \\
\text { Rheumatology. } \\
2007\end{array}$ & $F / 48$ & CS/MTX & 258 & 580 & NA & $\begin{array}{l}\text { Cidofovir, } \\
\text { mirtazapine, and } \\
\text { HCQ }\end{array}$ & Good & Improve \\
\hline $\begin{array}{l}\text { De Raedt S et al. } \\
\text { Clin Neurol } \\
\text { Neurosurg. } 2008\end{array}$ & $M / 43$ & No & 0 & NA & 88 & $\begin{array}{l}\text { Cidofovir and } \\
\text { steroids }\end{array}$ & Stable & Stabilization \\
\hline $\begin{array}{l}\text { Le Guilloux J et al. } \\
\text { Rev Neurol (Paris). } \\
2009\end{array}$ & $\mathrm{M} / 42$ & $\mathrm{CS} / \mathrm{HCQ}$ & 144 & NA & NA & $\begin{array}{l}\text { Cidofovir and IL2 } \\
(4,5 \mathrm{MIU} 2 / \mathrm{d})\end{array}$ & $\begin{array}{l}\text { Bad } \\
\text { (worsening) }\end{array}$ & Death \\
\hline $\begin{array}{l}\text { Granot R et al.J Clin } \\
\text { Neurosci. } 2009\end{array}$ & $M / 49$ & CS & 11 & NA & NA & Cidofovir & $\begin{array}{l}\text { Bad } \\
\text { (worsening) }\end{array}$ & Death \\
\hline $\begin{array}{l}\text { Neeb L et al. J } \\
\text { Neurol. } 2009\end{array}$ & $\mathrm{~F} / 56$ & & 228 & 310 & NA & Cidofovir & $\begin{array}{l}\text { Bad } \\
\text { (worsening) }\end{array}$ & Death \\
\hline $\begin{array}{l}\text { Yagi T et al. Clin } \\
\text { Neurol Neurosurg. } \\
2010\end{array}$ & $M / 34$ & No & 156 & NA & NA & Cidofovir & Good & Improve \\
\hline $\begin{array}{l}\text { Goldbecker A et al. } \\
\text { Int J Infect Dis. } 2010\end{array}$ & $\mathrm{~F} / 50$ & No & 240 & Normal & Normal & CS and acyclovir & Good & \\
\hline
\end{tabular}


Table 2 Literature review of PML cases and sarcoidosis (continued)

\begin{tabular}{|c|c|c|c|c|c|c|c|c|}
\hline References & $\begin{array}{l}\text { Cases (sex/ } \\
\text { age at PML } \\
\text { diagnosis, y) }\end{array}$ & $\begin{array}{l}\text { Therapies } \\
\text { before } \\
\text { PML }\end{array}$ & $\begin{array}{l}\text { Time from } \\
\text { diagnosis of } \\
\text { sarcoidosis to } \\
\text { PML (mo) }\end{array}$ & $\begin{array}{l}\text { Lymphocyte } \\
\text { count } \\
\left(/ \mathrm{mm}^{3}\right)\end{array}$ & $\begin{array}{l}\mathrm{CD4}^{+} \\
\text {count } \\
\left(/ \mathrm{mm}^{3}\right)\end{array}$ & Treatment & Tolerance & $\begin{array}{l}\text { Outcome } \\
\text { of PML }\end{array}$ \\
\hline $\begin{array}{l}\text { Gofton TE et al.J } \\
\text { Neurol Neurosurg } \\
\text { Psychiatr. } 2011\end{array}$ & $\mathrm{~F} / 54$ & CS & 72 & 310 & NA & Cidofovir & $\begin{array}{l}\text { Bad } \\
\text { (worsening) }\end{array}$ & Death \\
\hline $\begin{array}{l}\text { Park JH et al. Case } \\
\text { Rep Neurol. } 2011\end{array}$ & $\mathrm{M} / 45$ & CS & 4 & NA & NA & $\begin{array}{l}\text { Cidofovir and } \\
\text { mirtazapine }\end{array}$ & Good & Improve \\
\hline $\begin{array}{l}\text { Hohfeld SK et al. } \\
\text { BMJ Case Rep. } 2012\end{array}$ & $\mathrm{M} / 39$ & No & 0 & 600 & 171 & Mirtazapine & $\begin{array}{l}\text { Bad } \\
\text { (worsening) }\end{array}$ & Death \\
\hline $\begin{array}{l}\text { Keith J et al. } \\
\text { Neuropathology. } \\
2012\end{array}$ & $\mathrm{M} / 74$ & $\begin{array}{l}\text { CS/MTX/ } \\
\text { HCQ }\end{array}$ & NA & 300 & 260 & No & Bad & Death \\
\hline $\begin{array}{l}\text { Pallin M et al. QJM. } \\
2012\end{array}$ & $\mathrm{M} / 47$ & $\mathrm{CS} / \mathrm{HCQ}$ & 180 & 488 & 131 & $\begin{array}{l}\text { Cytarabine, } \\
\text { cidofovir, } \\
\text { mirtazapine, and } \\
\text { mefloquine }\end{array}$ & Good & Improve \\
\hline $\begin{array}{l}\text { Davis MJ et al. The } \\
\text { Neurologist. } 2013\end{array}$ & $F / 68$ & No & 0 & NA & 182 & No & NA & Death \\
\hline \multirow[t]{10}{*}{$\begin{array}{l}\text { Jamilloux Y et al. } \\
\text { Neurology. } 2014\end{array}$} & $\mathrm{M} / 40$ & CS & 146 & 300 & 167 & $\begin{array}{l}\text { Cidofovir and } \\
\text { mirtazapine }\end{array}$ & Good & Improve \\
\hline & $M / 24$ & $\begin{array}{l}\text { CS, MTX, } \\
\text { CYC, and } \\
\text { aTNFa }\end{array}$ & 96 & 1,299 & NA & No & NA & Improve \\
\hline & $\mathrm{M} / 41$ & No & 0 & 1,530 & 354 & $\begin{array}{l}\text { Cytarabine and } \\
\text { mirtazapine }\end{array}$ & Good & Improve \\
\hline & $F / 32$ & No & 171 & 1,620 & 426 & No & NA & Death \\
\hline & $\mathrm{M} / 42$ & $\begin{array}{l}\text { CS, MTX, } \\
\text { and HCQ }\end{array}$ & 67 & NA & 131 & Cidofovir and IL2 & $\begin{array}{l}\text { Bad } \\
\text { (worsening } \\
\text { of PML) }\end{array}$ & Death \\
\hline & $\mathrm{M} / 35$ & CS & 38 & 900 & NA & $\begin{array}{l}\text { Cidofovir and } \\
\text { mirtazapine }\end{array}$ & Good & Stabilization \\
\hline & $\mathrm{M} / 27$ & $\begin{array}{l}\text { CS and } \\
\text { MTX }\end{array}$ & 138 & 720 & NA & Mefloquine & NA & Death \\
\hline & $M / 37$ & CS & 0 & 500 & 115 & IL2 & $\begin{array}{l}\text { Medium } \\
\text { (cutaneous } \\
\text { rash) }\end{array}$ & Death \\
\hline & $F / 36$ & CS & 332 & 830 & 101 & Cidofovir & Good & Death \\
\hline & $M / 35$ & $\begin{array}{l}\text { CS, MTX, } \\
\text { and HCQ }\end{array}$ & 147 & 900 & NA & Cidofovir and IL2 & NA & Death \\
\hline $\begin{array}{l}\text { Lefaucheur R et al. } \\
\text { Neurology. } 2014\end{array}$ & $\mathrm{M} / 30$ & CS & 60 & NA & NA & $\begin{array}{l}\text { Mirtazapine, } \\
\text { mefloquine, and } \\
\text { IVlg }\end{array}$ & NA & Improve \\
\hline $\begin{array}{l}\text { Scholten P et al. } \\
\text { BMJ Case Rep. } 2017\end{array}$ & $\mathrm{M} / 57$ & No & 0 & NA & 240 & Mirtazapine & $\begin{array}{l}\text { Bad } \\
\text { (worsening) }\end{array}$ & Death \\
\hline $\begin{array}{l}\text { Duréault et al. } \\
\text { Medicine. } 2017\end{array}$ & $\mathrm{M} / 69$ & No & 3 & $<200$ & 34 & Cidofovir & NA & Death \\
\hline \multirow[t]{3}{*}{$\begin{array}{l}\text { Gamperl I et al. Clin } \\
\text { Case Rep. } 2018\end{array}$} & $F / 73$ & No & 24 & 680 & NA & $\begin{array}{l}\text { Steroids (pulse) } \\
\text { and mirtazapine }\end{array}$ & Good & Alive \\
\hline & $F / 54$ & $\begin{array}{l}\text { Steroids } \\
\text { and MMF }\end{array}$ & 72 & NA & NA & Mirtazapine & $\begin{array}{l}\text { IRIS and } \\
\text { then } \\
\text { improve }\end{array}$ & Alive \\
\hline & $F / 63$ & No & NA & NA & NA & No & $\begin{array}{l}\text { Bad } \\
\text { (worsening) }\end{array}$ & Death \\
\hline
\end{tabular}


Table 2 Literature review of PML cases and sarcoidosis (continued)

\begin{tabular}{|c|c|c|c|c|c|c|c|c|}
\hline References & $\begin{array}{l}\text { Cases (sex/ } \\
\text { age at PML } \\
\text { diagnosis, y) }\end{array}$ & $\begin{array}{l}\text { Therapies } \\
\text { before } \\
\text { PML }\end{array}$ & $\begin{array}{l}\text { Time from } \\
\text { diagnosis of } \\
\text { sarcoidosis to } \\
\text { PML (mo) }\end{array}$ & $\begin{array}{l}\text { Lymphocyte } \\
\text { count } \\
\left(/ \mathrm{mm}^{3}\right)\end{array}$ & $\begin{array}{l}\mathrm{CD4}^{+} \\
\text {count } \\
\left(/ \mathrm{mm}^{3}\right)\end{array}$ & Treatment & Tolerance & $\begin{array}{l}\text { Outcome } \\
\text { of PML }\end{array}$ \\
\hline Total & $\begin{array}{l}27 \mathrm{M} / 14 \mathrm{~F} \\
47(24 ; 74)\end{array}$ & & $85,9(0 ; 332)$ & $\begin{array}{l}750 \\
(300 ; 1620)\end{array}$ & $\begin{array}{l}210 \\
(34 ; 500)\end{array}$ & & & $\begin{array}{l}24 / 39 \\
(61.5 \%)\end{array}$ \\
\hline
\end{tabular}

Abbreviations: aTNFa = anti-TNFa; CS = corticosteroids; CYC = cyclophosphamide; HCQ = hydroxychloroquine; IRIS = immune reconstitution inflammatory syndrome; IVIg = IV immunoglobulin; MIU = million international unit; MMF = mycophenolate mofetil; $M$ TX = methotrexate; NA = not available; PML = progressive multifocal encephalopathy; TNF = tumor necrosis factor.

In sarcoidosis, CD4 T-cell depletion is mainly linked to the margination process. Thus, the use of IL7 as a therapy for PML has probably favored the expansion and activation of CD4 $\mathrm{T}$ cells in tissue, explaining the IRIS in involved tissue (lung and lymph nodes) and hypercalcemia. We chose to introduce low dose of steroids and hydroxychloroquine to balance the related risk of PML resurgence and immune restoration syndrome associated with granuloma activity (hypercalcemia and acute lung injury) and sebopsoriasis flare. $^{10}$

New targeted therapies in immunology and infectiology open the doors of more specific and more specialized therapies for patients with immunodeficiencies, autoimmune diseases, or cancers. Nonetheless, some imbalance has to be finely found to avoid some severe complications. This is the beginning of a new era for physicians involved in these fields.

\section{Study funding}

Supported by the European regional development fund (European Union) INTERREG V program (project PERSONALIS) and the MSD Avenir grant (Autogen project).

\section{Disclosure}

The authors report no disclosures relevant to the manuscript. Go to Neurology.org/NN for full disclosures.

\section{Publication history}

Received by Neurology: Neuroimmunology \& Neuroinflammation April 27, 2020. Accepted in final form June 15, 2020.

Appendix Authors

\begin{tabular}{lll}
\hline Name & Location & Contribution \\
\hline $\begin{array}{l}\text { Aurélien } \\
\text { Guffroy, MD, } \\
\text { PhD }\end{array}$ & $\begin{array}{l}\text { Strasbourg } \\
\text { University } \\
\text { Hospital, France }\end{array}$ & $\begin{array}{l}\text { Designed and performed the } \\
\text { study, wrote the paper, } \\
\text { coordinated the care of the } \\
\text { patient, and read and accepted } \\
\text { the paper in the final version }\end{array}$ \\
\hline $\begin{array}{l}\text { Morgane Solis, } \\
\text { PharmD, PhD }\end{array}$ & $\begin{array}{l}\text { Strasbourg } \\
\text { University } \\
\text { Hospital, France }\end{array}$ & $\begin{array}{l}\text { Performed the study, involved in } \\
\text { patient care, and read and } \\
\text { accepted the paper in the final } \\
\text { version }\end{array}$ \\
\hline
\end{tabular}

Appendix (continued)

\begin{tabular}{|c|c|c|}
\hline Name & Location & Contribution \\
\hline $\begin{array}{l}\text { Vincent Gies, } \\
\text { PharmD, PhD }\end{array}$ & $\begin{array}{l}\text { Strasbourg } \\
\text { University } \\
\text { Hospital, France }\end{array}$ & $\begin{array}{l}\text { Performed the study and wrote, } \\
\text { read, and accepted the paper in } \\
\text { the final version }\end{array}$ \\
\hline $\begin{array}{l}\text { Yannick } \\
\text { Dieudonne, } \\
\text { MD }\end{array}$ & $\begin{array}{l}\text { Strasbourg } \\
\text { University } \\
\text { Hospital, France }\end{array}$ & $\begin{array}{l}\text { Performed the study and wrote, } \\
\text { read, and accepted the paper in } \\
\text { the final version }\end{array}$ \\
\hline $\begin{array}{l}\text { Cornelia } \\
\text { Kuhnert, MD }\end{array}$ & $\begin{array}{l}\text { Strasbourg } \\
\text { University } \\
\text { Hospital, France }\end{array}$ & $\begin{array}{l}\text { Involved in patient care and } \\
\text { collecting the data and read and } \\
\text { accepted the paper in the final } \\
\text { version }\end{array}$ \\
\hline $\begin{array}{l}\text { Cédric } \\
\text { Lenormand, } \\
\text { MD, PhD }\end{array}$ & $\begin{array}{l}\text { Strasbourg } \\
\text { University } \\
\text { Hospital, France }\end{array}$ & $\begin{array}{l}\text { Involved in patient care and } \\
\text { collecting the data and read and } \\
\text { accepted the paper in the final } \\
\text { version }\end{array}$ \\
\hline $\begin{array}{l}\text { Laurent } \\
\text { Kremer, MD, } \\
\text { PhD }\end{array}$ & $\begin{array}{l}\text { Strasbourg } \\
\text { University } \\
\text { Hospital, France }\end{array}$ & $\begin{array}{l}\text { Involved in patient care and } \\
\text { collecting the data and read and } \\
\text { accepted the paper in the final } \\
\text { version }\end{array}$ \\
\hline $\begin{array}{l}\text { Anne Molitor, } \\
\text { PhD }\end{array}$ & $\begin{array}{l}\text { Strasbourg } \\
\text { University } \\
\text { Hospital, France }\end{array}$ & $\begin{array}{l}\text { Interpreted the data of whole- } \\
\text { exome sequencing and read and } \\
\text { accepted the paper in the final } \\
\text { version }\end{array}$ \\
\hline $\begin{array}{l}\text { Raphaël } \\
\text { Carapito, PhD }\end{array}$ & $\begin{array}{l}\text { Strasbourg } \\
\text { University } \\
\text { Hospital, France }\end{array}$ & $\begin{array}{l}\text { Interpreted the data of whole- } \\
\text { exome sequencing and read and } \\
\text { accepted the paper in the final } \\
\text { version }\end{array}$ \\
\hline $\begin{array}{l}\text { Yves } \\
\text { Hansmann, } \\
\text { MD, PhD }\end{array}$ & $\begin{array}{l}\text { Strasbourg } \\
\text { University } \\
\text { Hospital, France }\end{array}$ & $\begin{array}{l}\text { Involved in patient care and } \\
\text { collecting the data and read and } \\
\text { accepted the paper in the final } \\
\text { version }\end{array}$ \\
\hline $\begin{array}{l}\text { Vincent } \\
\text { Poindron, MD, } \\
\text { PhD }\end{array}$ & $\begin{array}{l}\text { Strasbourg } \\
\text { University } \\
\text { Hospital, France }\end{array}$ & $\begin{array}{l}\text { Involved in patient care and } \\
\text { collecting the data and read and } \\
\text { accepted the paper in the final } \\
\text { version }\end{array}$ \\
\hline $\begin{array}{l}\text { Thierry } \\
\text { Martin, MD, } \\
\text { PhD }\end{array}$ & $\begin{array}{l}\text { Strasbourg } \\
\text { University } \\
\text { Hospital, France }\end{array}$ & $\begin{array}{l}\text { Involved in patient care and } \\
\text { collecting the data and read and } \\
\text { accepted the paper in the final } \\
\text { version }\end{array}$ \\
\hline $\begin{array}{l}\text { Sandrine } \\
\text { Hirschi, MD }\end{array}$ & $\begin{array}{l}\text { Strasbourg } \\
\text { University } \\
\text { Hospital, France }\end{array}$ & $\begin{array}{l}\text { Performed the study, involved in } \\
\text { patient care, and wrote, read, and } \\
\text { accepted the paper in the final } \\
\text { version }\end{array}$ \\
\hline $\begin{array}{l}\text { Anne-Sophie } \\
\text { Korganow, } \\
\text { MD, PhD }\end{array}$ & $\begin{array}{l}\text { Strasbourg } \\
\text { University } \\
\text { Hospital, France }\end{array}$ & $\begin{array}{l}\text { Performed the study, involved in } \\
\text { patient care, and wrote, read, and } \\
\text { accepted the paper in the final } \\
\text { version }\end{array}$ \\
\hline
\end{tabular}




\section{References}

1. Jamilloux Y, Néel A, Lecouffe-Desprets M, et al. Progressive multifocal leukoencephalopathy in patients with sarcoidosis. Neurology 2014;82:1307-1313.

2. Cortese I, Muranski P, Enose-Akahata Y, et al. Pembrolizumab treatment for progressive multifocal leukoencephalopathy. N Engl J Med 2019;380: $1597-1605$.

3. Walter O, Treiner E, Bonneville F, et al. Treatment of progressive multifocal leukoencephalopathy with nivolumab. N Engl J Med 2019;380:1674-1676.

4. Sospedra M, Schippling S, Yousef S, et al. Treating progressive multifocal leukoencephalopathy with interleukin 7 and vaccination with JC virus capsid protein VP1. Clin Infect Dis 2014;59:1588-1592.

5. Duréault A, Chapelon C, Biard L, et al. Severe infections in sarcoidosis: incidence, predictors and long-term outcome in a cohort of 585 patients. Medicine 2017;96: e8846.
6. Jamilloux $\mathrm{Y}$, Valeyre D, Lortholary $\mathrm{O}$, et al. The spectrum of opportunistic diseases complicating sarcoidosis. Autoimmun Rev 2015;14:64-74.

7. In the frame of GSF (Groupe Sarcoïdose France), Calender A, Rollat Farnier PA, Buisson A, et al. Whole exome sequencing in three families segregating a pediatric case of sarcoidosis. BMC Med Genomics 2018;11:23.

8. Zerbe CS, Marciano BE, Katial RK, et al. Progressive multifocal leukoencephalopathy in primary immune deficiencies: stat 1 gain of function and review of the literature. Clin Infect Dis 2016;62:986-994.

9. Krey L, Raab P, Sherzay R, et al. Severe progressive multifocal leukoencephalopathy (PML) and spontaneous immune reconstitution inflammatory syndrome (IRIS) in an immunocompetent patient. Front Immunol 2019;10:1188.

10. Tripathi SV, Leslie KS, Maurer TA, Amerson EH. Psoriasis as a manifestation of HIV related immune reconstitution inflammatory syndrome. J Am Acad Dermatol 2015; 72:e35-e36. 


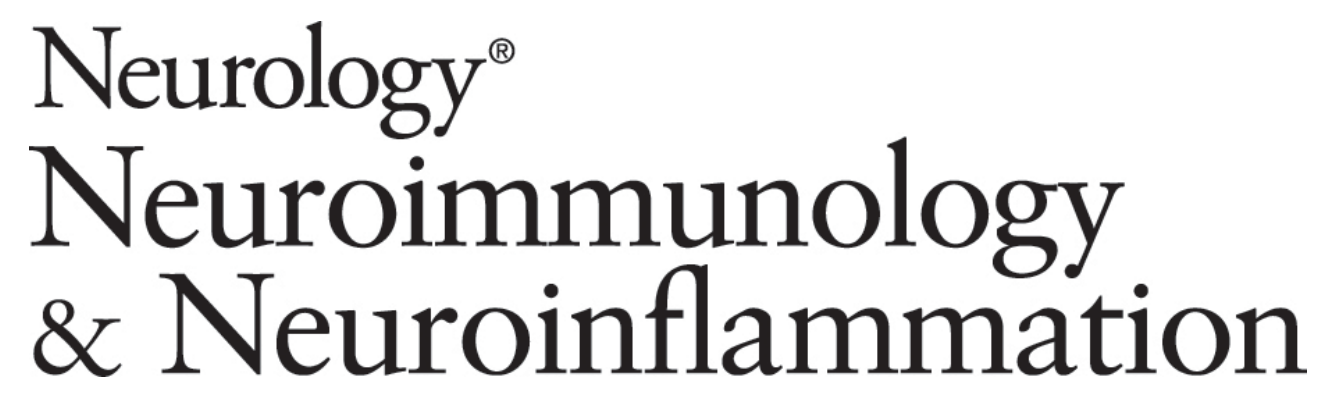

Progressive multifocal leukoencephalopathy and sarcoidosis under interleukin 7: The price of healing

Aurélien Guffroy, Morgane Solis, Vincent Gies, et al.

Neurol Neuroimmunol Neuroinflamm 2020;7;

DOI 10.1212/NXI.0000000000000862

This information is current as of August 11, 2020

Neurol Neuroimmunol Neuroinflamm is an official journal of the American Academy of Neurology.

Published since April 2014, it is an open-access, online-only, continuous publication journal. Copyright

Copyright $\odot 2020$ The Author(s). Published by Wolters Kluwer Health, Inc. on behalf of the American

Academy of Neurology.. All rights reserved. Online ISSN: 2332-7812.

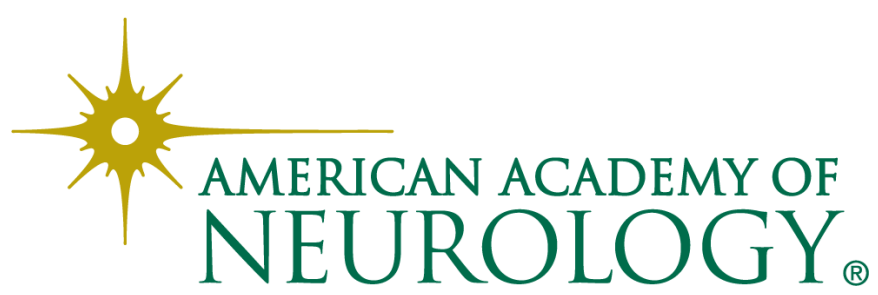




\section{Updated Information \& Services}

References

Subspecialty Collections

Permissions \& Licensing

\section{Reprints}

including high resolution figures, can be found at: http://nn.neurology.org/content/7/5/e862.full.html

This article cites 10 articles, 0 of which you can access for free at: http://nn.neurology.org/content/7/5/e862.full.html\#\#ref-list-1

This article, along with others on similar topics, appears in the following collection(s):

All Demyelinating disease (CNS)

http://nn.neurology.org//cgi/collection/all_demyelinating_disease_cns Aphasia

http://nn.neurology.org//cgi/collection/aphasia

Autoimmune diseases

http://nn.neurology.org//cgi/collection/autoimmune_diseases

MRI

http://nn.neurology.org//cgi/collection/mri

\section{Viral infections}

http://nn.neurology.org//cgi/collection/viral_infections

Information about reproducing this article in parts (figures,tables) or in its entirety can be found online at:

http://nn.neurology.org/misc/about.xhtml\#permissions

Information about ordering reprints can be found online: http://nn.neurology.org/misc/addir.xhtml\#reprintsus

Neurol Neuroimmunol Neuroinflamm is an official journal of the American Academy of Neurology.

Published since April 2014, it is an open-access, online-only, continuous publication journal. Copyright

Copyright $\odot 2020$ The Author(s). Published by Wolters Kluwer Health, Inc. on behalf of the American Academy of Neurology.. All rights reserved. Online ISSN: 2332-7812.

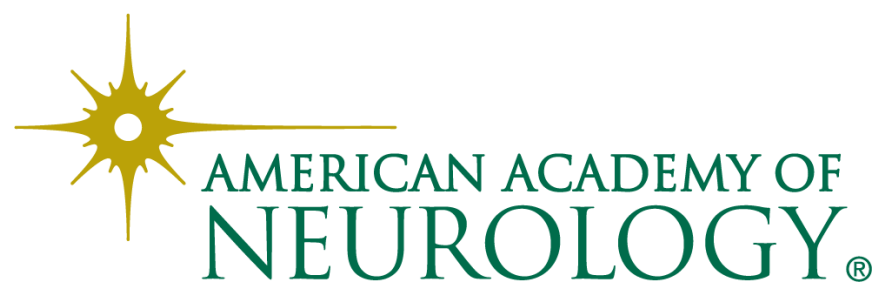

